\title{
Gender \\ Mainstreaming in Vienna \\ How the Gender Perspective Can Raise the Quality of Life in a Big City
} set the framework for equal opportunities. In the context of gender mainstreaming, this means that gender-caused differences have to be considered systematically in the provision of public services such as housing and mobility, education and child-care facilities, as well as health care and care for the elderly, as these services are crucial for gender equality. The city of Vienna is determined to consider social changes continuously, hence improving equality between women and men is considered an important topic on the city's agenda. Since the beginning of the 1990s there has been a clear political commitment to a policy of equality of opportunity.

The promotion of women has played an important role in Vienna for more than fifteen years. A municipal department for the promotion and coordination of women's affairs was created in 1992. This has encouraged a gender-sensitive approach in various parts of the city administration, be 
it in human resource management, town planning issues, labour market policies, public health or education policy. Since the 1990s various pilot projects and specific programmes for the promotion of women and girls have been set up. The support of such projects and funding of associations and NGOs focusing on feminist concerns or the provision of assistance and counselling are a priority for the women's department. Since the end of the 1990s the concept has been broadened in order to make gender issues more cross-sectional. Gender politics can only be efficient if they do not remain the concern of one municipal department alone. The entire city administration has to be concerned with and to make gender aspects a consistent part of every project and every public service. Therefore gender mainstreaming differs from programmes for the promotion of women mainly in its perspective. Gender mainstreaming is preventive in nature and tackles the equality issue right from the beginning of a project or a political strategy when, for example, developing new public services, while the promotion of women's issues 'patches up' problems that already exist in society.

The City Councillor for Women's Issues, Sandra Frauenberger, summarises the political requirements for Vienna as follows:

"The introduction of gender mainstreaming within an organisation aims at changing objectives, structures, processes and organisational culture. Therefore it cannot be implemented on an ad-hoc basis achieving immediately measurable results, but only within an organisational development process which requires a systematic approach and an appropriate amount of time. This on-going learning process needs active management and control.” (Bauer 2008:64)

This political commitment also appears in the following statement by Chief Executive Director Ernst Theimer: "We regard gen- der mainstreaming as an important instrument to ensure best possible customer orientation" (Bauer 2008:64). Therefore a project manager was installed in the Chief Executive Office of the Executive Group for Organisation, Safety and Security in 2005. The project office is in charge of managing the implementation process and is charged with developing strategic objectives in accordance with relevant stakeholders, such as the City Councillor for Women's Issues and the senior management. A coordination platform and a pool of gender experts have been established to meet the ever-growing demand for information, counselling and further training throughout the city administration.

Positioning gender mainstreaming at the senior management level has proved beneficial in many ways. First it gives a clear signal, since equality issues have traditionally not been a top priority of either specialists or executive staff. Secondly gender screenings serve as an additional quality check and provide a sound basis for decisions by

- drawing attention to gender-caused differences in all policy areas;

- considering all users of public services and their different needs with a special focus on gender, as well as with regard to social, ethnic and health-related differences.

Consequently the implementation process was built upon the following three pillars. First a strong emphasis was placed on awareness raising and on building adequate know-how for practical application as a basis for further action. The second step was to set up an efficient and sustainable reporting system aimed at providing information about progress, but also to refer to gender issues on a regular basis. In the third place, it was necessary to make the changes visible to the public by means of pilot projects.

The success of these policies is already visible in many areas, such as labour market 
policies and the design and planning of public spaces, parks, playgrounds and daycare centres. 42 of 70 municipal departments have already implemented gender measures.

\section{AWARENESS RAISING AND BUILDING ADEQUATE KNOW-HOW}

Gender stereotypes are the most important obstacles to gender equality. Gender mainstreaming aims above all at changing socially defined stereotyped gender roles that all too often lead to discrimination against women, and sometimes also against men. Changes in behaviour require awarenessraising measures and training.

In order to raise awareness and inform the approximately 59,000 employees of the Vienna City Administration, in December 2006 the Executive City Councillor for Women's Issues and the Chief Executive Director of the City Administration launched a campaign with the slogan "Take a different perspective! Vienna is gender mainstreaming." The campaign showed familiar images in an unfamiliar way and centred on commonly known pictographs and signs, but with reversed gender roles. ${ }^{1}$

Posters and print ads have been designed to raise awareness for gender equality. By playing with expectations, the campaign encourages changes to ways of thinking and perceptions of traditional gender roles. The new pictographs have not been limited to posters. Changing tables in public restrooms will now, for example, also be indicated by signs showing a man changing a baby. Vienna Public Transport has also participated in the gender mainstreaming campaign: the pictographs that ask passengers to give their seats to elderly and disabled persons and people with small children have been redesigned. The old and new signs are now used side by side. At first glance the new signs on the underground and tram look the same, but at second glance people will notice the difference: where the pictograph used to show a mother with a toddler on her lap, there is now also the image of a father with a child on his lap.

The campaign was set out to be provocative and created an intensive discussion on gender roles and expectations both within and outside the city administration. Men in particular complained about wasting money for some "stupid signs" and suggested that the city of Vienna ought to deal with more important problems of daily life. A Mr Kaida, a retired safety expert, even went so far as to claim that a change of exit signs would put men especially at risk. In cases of emergency, men might think that a sign showing a woman indicated an emergency exit only for women (Mayr 2007:11). ${ }^{2}$

This comment shows best why the campaign has been so important and has generated so much emotion: like many other languages, as well as almost all common pictographs and icons, the German language takes men as a standard. Women have to content themselves with being invisible or an exception. On the other hand, creating politically correct signs that show women and men on an equal basis turned out to be a difficult exercise. For ease of identification, women were presented with traditional feminine attributes like long hair and skirts. Exactly this fact caused harsh comments from both women and men, who identified this strong emphasis on female attributes as just another example of stupid gender stereotypes.

In any case, discussing gender issues will often return to the question: "Is it necessary to point out differences between women and men and to confront them with the fact that they are still not treated equally?" Judging from the Viennese experience, drawing attention to existing differences and making gender-caused discrimination visible is a necessary first step towards changing attitudes.

Therefore, in addition to this awarenessraising campaign, the city also provides 
training for its employees to support them in these matters. Equality is an integral part of training and further training, from newcomer training to management courses, and has also been firmly integrated into the internal training programmes of some departments (Vienna Children's Day Care Centres, Social Welfare, Social and Public Health Law, Vienna Social Welfare Fund, Vienna Hospital Association). About three hundred individuals take part in information and further training events each year.

\section{SETTING UP A SUSTAINABLE REPORTING SYSTEM}

Sustainable changes in behaviour can only be achieved through the identification of clear targets and the creation of facts. Moral arguments and in-depth gender training will provide a stimulus but do not necessarily cause a change in everyday work routines and, what is more important, take far too long to become effective. Clear requirements in planning handbooks or routine reports, such as the gender budgeting report, on the other hand, require the issue to be addressed on a regular basis and thus lead to sustainable change.

Gender budgeting is the systematic consideration of the different living situations of women and men in the budgeting process. The focus is placed on the following questions: who benefits from financial sources and services, how are the services utilised by the public, and does the way in which the resources are distributed contribute to the reduction or the increase of existing differences between women and men? This makes gender budgeting a perfect trigger for greater gender equality.

Since 2005, these questions have formed an integral part of Vienna's budgeting process. In preparing their budget estimates and annual accounts, all municipal departments are called upon to examine closely their objectives and accomplishment of tasks on the one hand and the resources needed for that purpose on the other. This constitutes an ideal time to examine the gender relevance of the objectives and the distribution of resources. The gender budgeting reports provide information on the extent to which gender-related objectives are considered in departments' budget estimates, the extent to which measures to achieve these objectives are being taken, the current beneficiaries of the expenditure and the indicators which may be used to measure progress. ${ }^{3}$

This analysis questions procedures and services - the precise gender screening of who benefits from which products, services and financial means proved to be a trigger for reconsidering the actual target group, as well as for drawing up new strategies and solutions within municipal departments, leading to innovative new pilot projects such as the gender-sensitive planning of a school playground. The introduction to the usual budgeting process guarantees an overall learning process, which increases the chance of sustainability.

Another important aspect of gender budgeting is to raise the interest of the public in the budgeting process. Meidling, the $12^{\text {th }}$ district of Vienna, has therefore presented its preliminary budget of 2009 in a more accessible way. In addition to the conventional and rather technical reports, a huge banner was displayed at the local district council building showing the presumed expenses for the district's services, as well as the political aims, gender-specific objectives and information about the most important target groups.

\section{MAKING CHANGES VISIBLE}

The design and structure of the urban environment have a vital influence on the life situations of the people who live there and also define the contexts of their everyday lives.

Many shortcomings in public space affect women and girls more than men. 
PRELIMINARY BUDGET - DATA ENTRY FORM

\begin{tabular}{|c|c|c|c|c|c|}
\hline $\begin{array}{c}\text { municipal } \\
\text { department }\end{array}$ & $\begin{array}{c}\text { budget } \\
\text { item }\end{array}$ & $\begin{array}{c}\text { gender specific } \\
\text { targets }\end{array}$ & $\begin{array}{c}\text { intended } \\
\text { projects } \\
\text { and actions }\end{array}$ & $\begin{array}{c}\text { intended } \\
\text { outcome and } \\
\text { success factors }\end{array}$ & $\begin{array}{c}\text { stakeholders and } \\
\text { customers } \\
\text { distinguished by sex }\end{array}$ \\
\hline
\end{tabular}

STATEMENT OF ACCOUNTS - DATA ENTRY FORM

\begin{tabular}{|c|c|c|c|c|}
\hline $\begin{array}{c}\text { municipal } \\
\text { department }\end{array}$ & $\begin{array}{c}\text { budget } \\
\text { item }\end{array}$ & $\begin{array}{c}\text { gender specific } \\
\text { targets }\end{array}$ & $\begin{array}{c}\text { projects and actions } \\
\text { taken to reduce } \\
\text { gender gaps }\end{array}$ & $\begin{array}{c}\text { success } \\
\text { factors }\end{array}$ \\
\hline
\end{tabular}

Gender budget entry forms, City of Vienna, Municipal Department 5 - Financial Affairs.

Women use public transport more frequently, they are still responsible for most of the care work and therefore often accompany the slowest traffic users (small children, frail and older persons), and the risk of sexual harassment is still a fact of life. As a result, gender-sensitive planning turned out to be the most tangible example for implementing gender mainstreaming in Vienna. Pilot projects were initiated in specific parts of the city such as park planning, housing design, pedestrian-friendly design and public transport under the guidance of the Coordination Office for Planning and Construction Geared to the Requirements of Daily Life and the Specific Needs of Women. 4

In 2002, Mariahilf, the $6^{\text {th }}$ municipal district of Vienna, became a gender mainstreaming pilot district. The district level was chosen because it provides a clear impression of different everyday interactions (Magistratsdirektion-Baudirektion, Leitstelle Frauen und Alltagsgerechtes Planen und Bauen, 2005:5). All the departments responsible for public space in Mariahilf held joint workshops and individual consultations and developed specific methods to optimise measures in order to increase equal opportunities in public space. In 2002 , a set of maps was made available de- picting the qualities and shortcomings of the pedestrian-path network. This district also received a manual of gender-sensitive perspectives for traffic and transport planning. The main challenge was to integrate the interests of pedestrians into traffic and transport planning methodically and to put them on an equal footing with other interests.

The results and experiences derived from the pilot served as a sound basis for developing checklists and guidelines that were integrated into common process schemes, planning handbooks and quality systems: when planning a new road or a new square, it will be important to ask the right questions right at the start, during the analysis of the initial situation. Are there any district service centres, associations or schools in the relevant area? Are data collected in a gender-sensitive way, e.g. when recording pedestrian flows, and are these findings considered equally important as car traffic data? This has an influence on the planning of traffic-light times and the location of pedestrian crossings. Do the plans take account of gaps in the overall network of pedestrian walkways? A pavement widening, for example in front of a school, is a positive measure. However, if it is the only measure it will be of little benefit, for 
example, if, in order to get there, children have to use narrow walkways, that is, less than $2 \mathrm{~m}$ wide, or have to cross the street at intersections without traffic lights or pedestrian crossings. Therefore, Municipal Department 28, which is responsible for road management and construction, has introduced a specific checklist to assess pedestrians' interests when planning new projects.

Municipal Department 29, which is responsible for all bridges, footbridges and public steps in the city, responded to the citizens' different needs by preparing an action plan for pedestrians, which provides for an inspection of public steps in terms not only of technical safety, but also of subjective safety and barrier-free access. However, the two departments do not content themselves with considering gender aspects in relation to customer interests. In order to increase the number of qualified female staff in this male-dominated sphere, they have initiated specific programmes to promote female employees.

Moreover, gender aspects are also important with regard to technical standards. A new lighting standard 5 takes account of pedestrians' interests when determining the illumination level as such, but it does not consider pedestrians' feelings of subjective safety, which cannot be measured by objective data. Therefore, Municipal Department 33 (Public Lighting) has integrated a checklist with these criteria into its planning handbook. These criteria include, for example, whether there are any alternative routes, whether the walkway offers good orientation, whether there are any problem groups in the area, whether there is social control (local residents), and whether the walkway is within sight and hearing distance of residential property.

\section{CONCLUSIONS}

The central aims of the efforts include creating acceptance for the equal treatment of women and men in all departments of the city administration, building adequate know-how for practical application, and particularly initiating the structured integration within the system to ensure the sustainable establishment of the principle beyond visible but often one-time pilot projects.

The experiences gained in Vienna in the past few years revealed that the number of parties interested in this subject and acting in a gender-competent way is continually increasing. After rather discouraging comments at the beginning of the 1990s, such as "So let's paint the pavements pink!" and the essential question of "Why do we need this? It does not make any difference in our department anyway!", considerations have become more pragmatic and since 2007 have focused on the issue of implementation and on the question of "How can we get it right?" (Bauer 2008:67).

Numerous changes will not seem spectacular at first glance. Taken together, however, individual achievements, such as more flexible opening hours, better street lighting, call systems for technology and business promotion schemes, which include genderrelevant topics and require specification of the share of women in the applicant's staff structure, well-equipped toilet facilities featuring baby-changing tables but which are also accessible to men, a higher share of male kindergarten staff and male staff at pensioners' clubs as well as gender-sensitive language will actually lead to an improvement in the gender ratio and to more room for action for women and men alike.

As Kerstin Dörhöfer, the doyenne of feminist architecture, brilliantly put it, "Women's idea of utopia is the subversion of everyday systems becoming manifest in 100,000 small things. The sum of the subverted elements would create totally different cities" (Dörhöfer 1993:101). 


\section{Notes}

1. http://www.wien.gv.at/menschen/gendermainstreaming/pdf/projektstelle.pdf

2 . The gendered emergency exit sign turned out to be the most discussed sign of the entire campaign. Formally speaking, we have always been aware that some signs cannot be changed by the city of Vienna due to national and EU regulations. The new pictograms were designed to draw attention to the fact that most signs in public spaces focus on men. Women only appear when it comes to indicating pedestrian zones and shopping streets. 3 . Gender budgeting reports are available at http://www.wien.gv.at/finanzen/budget/ 4. http://www.wien.gv.at/stadtentwicklung/alltagundfrauen/

5. Austrian Standard EN 13201.

\section{LITERATURE}

- Bauer, Ursula (2008): Genderkompetenz - eine wichtige Grundlage der modernen Verwaltung, in: Iris Appiano-Kugler and Traude Kogoj (ed.): Going Gender and Diversity. Facultas, Wien.

- Dörhöfer, Kerstin (1993): Stadt und Utopien, in: Buchmüller, Lydia and Barbara Zibell (eds.): Weibliche und männliche Aspekte in der Stadtplanung. Institut für Orts- Regional- und Landesplanung, ETH Zürich. (= ORL-Bericht 86/1993), Zürich.

- Mayr, Christian (2007): Flucht zurück: Aus für weibliche Notausgang-Tafeln, in: Wiener Zeitung 03.01.2007/2, p 11

- Magistratsdirektion-Baudirektion, Leitstelle Frauen und Alltagsgerechtes Planen und Bauen (ed.) (2005): Stadt fair teilen. Gender Mainstreaming in Mariahilf bietet für Franen und Männer, Mädchen und Burschen gleiche Chancen im Stadtraum, Wien.

Ursula Bauer, Mag.a

Project Manager Gender Mainstreaming

chief executive office

executive Group for Organisation, Safety and

Security

City of Vienna, Austria 